\title{
TEKNIK MITIGASI LIMPASAN PERMUKAAN PADA TIPOLOGI LAHAN PERMUKIMAN DAN PERDAGANGAN-JASA
}

\author{
LIGAL SEBASTIAN \\ Program Studi Teknik Sipil Fakultas Teknik Universitas Palembang \\ Jalan Dharmapala No.1A Bukit Besar Palembang 30139 \\ e-mail : ligal.oke@gmail.com
}

\begin{abstract}
The research was motivated by the fact that small-scale floods occur everywhere, including in the city of Palembang. Un-controlled surface runoff has been clearly understood as the cause of the flooding. The experts have been trying to find ways to overcome these problems, but have not done in an integrated manner. The main objective of this research was to study the surface runoff mitigation techniques in 2 (two) types of land use. The research method used, the study of literature, field surveys, and artificial rainfall experiment (rainfall simulator) on two types of land use with mitigation techniques in the treat-ment of rain harvesting, infiltration wells, infiltration biopori hole and green roofs. The results showed that the settlement of land acquired most of the holes infiltration biopori mitigate runoff that is equal to 338.33 liters or $54.71 \%$ of the control, whereas for the land of the tradeservice known to infiltration wells to mitigate most of the runoff that is equal to 428.67 liters or $42.35 \%$ of the control. Based on the test contrast, surface runoff mitigation techniques in residential and commercial - ser-vices land shows no signs of the dominant technique to each other. It is predicted that the factors causing the artificial rainfall intensities given in the experimental design including the criteria for very thick $(62.54 \mathrm{~mm})$, so that mitigation techniques are not able to manage the water with a maximum . In addition, soil types categorized easily water saturated makes very little the water is absorbed and the rest confined to the surface runoff.
\end{abstract}

Key words: surface runoff, mitigation techniques, the typology of land use

\begin{abstract}
ABSTRAK
Penelitian ini dilatarbelakangi oleh kenyataan bahwa banjir berskala kecil terjadi dimana-mana, termasuk di Kota Palembang. Tidak terkendalinya limpasan permukaan telah dipahami dengan jelas sebagai penyebab terjadinya banjir tersebut. Para ahli telah mencoba menemukan jalan keluar untuk mengatasi masalah tersebut, tetapi belum dilakukan secara terpadu. Tujuan utama dari penelitian ini adalah untuk mempelajari teknik mitigasi limpasan permukaan pada 2 (dua) tipe penggunaan lahan. Metode penelitian yang digunakan, yaitu studi literatur, survei lapangan, dan percobaan hujan buatan (rainfall simulator) pada dua tipe penggunaan lahan dengan perlakuan teknik mitigasi panen hujan, sumur resapan, lubang resapan biopori dan atap hijau. Hasil penelitian menunjukkan bahwa pada lahan permukiman didapat lubang resapan biopori paling besar me-mitigasi limpasan yaitu sebesar 338,33 liter atau sebesar 54,71\% dari kontrol, sedangkan untuk lahan perdagangan-jasa dike-tahui sumur resapan paling besar memitigasi limpasan yaitu sebesar 428,67 liter atau 42,35\% dari kontrol. Berdasarkan uji kontras, teknik mitigasi limpasan permukaan pada lahan permukiman dan perdagangan-jasa menunjukkan tidak adanya perla-kuan teknik yang dominan satu sama lainnya. Hal tersebut diprediksi faktor yang menyebabkannya adalah intensitas curah hujan buatan yang diberikan dalam rancang percobaan termasuk kriteria sangat lebat $(62,54 \mathrm{~mm})$, sehingga teknik mitigasi yang ada tidak mampu mengelola air dengan maksimal (terjadinya flooding). Selain itu, jenis tanah yang terkategori mudah jenuh air membuat air yang terserap terbatas dan sisanya menjadi limpasan permukaan.
\end{abstract}

Kata-kata kunci: limpasan permukaan, teknik mitigasi, dan tipologi penggunaan lahan 


\section{PENDAHULUAN}

Kebutuhan lahan di kawasan perkotaan saat ini, semakin meningkat sejalan dengan pertumbuhan penduduk dan kegiatan sosial ekonomi. Peningkatan kebutuhan lahan ini merupakan im-plikasi dari semakin beragamnya peran dan fungsi dari perkem-bangan fisik di kawasan perkotaan yang meliputi penggunaan lahan pertanian/perkebunan dan lahan nonpertanian seperti permu-kiman, pemerintahan, perdagangan dan jasa serta industri.

Sejalan dengan permintaan dan pemenuhan kebutuhan la-han, terjadi pergeseran fungsi atau alih fungsi yang terjadi di ka-wasan perkotaan dan pinggiran yaitu lahan yang tadinya diperuntukkan sebagai kawasan hutan, daerah resapan air dan pertani-an perkebunan berubah fungsi menjadi kawasan komersial. Ada-pun potensi dampak yang dapat terjadi akibat perubahan penggu-naan lahan tersebut adalah timbulnya dan dominannya limpasan permukaan meliputi rusaknya lahan produktif/erodibilitas lahan (pertanian/perkebunan, ladang dan tegalan), dan banjir/genangan lokal di berbagai kawasan permukiman. Apabila dikaitkan de-ngan terjadinya banjir yang disebabkan oleh rendahnya kemam-puan infiltrasi tanah, sehingga menyebabkan tanah tidak mampu lagi menyerap air. Selain itu, terjadinya banjir juga dapat disebabkan oleh limpasan permukaan yang meluap dan volumenya melebihi kapasitas pengaliran sistem drainase atau sistem aliran sungai (Haryani, et al., 2008).

Para ahli telah mencoba menemukan jalan keluar untuk me-ngatasi masalah tersebut, tetapi belum dilakukan secara terpadu. Sehubungan dengan permasalahan yang terjadi, maka diperlukan teknis pengendalian atau mitigasi limpasan permukaan ditujukan untuk mencegah, mengurangi adanya potensi limpasan yang dominan dan mereduksi genangan yang dapat terjadi secara lebih besar. Berdasarkan studi literatur dan beberapa penelitian lain-nya, maka teknik mitigasi limpasan permukaan yang dapat di-gunakan sebagai salah satu teknik pengendalian limpasan permu-kaan pada tiga tipologi lahan perkotaan diantaranya adalah sistem panen hujan, sumur resapan, atap hijau (green roof) dan lubang resapan biopori.

Sistem panen hujan pada prinsipnya melihat hujan (sebagai sumber atau source) ditampung pada areal tangkapan (catchment area), selanjutnya diteruskan atau disalurkan (menggunakan con-veyance) kepada sub-sistem penyimpanan atau penampungan (storage). Menurut Waterfall (2007) panen hujan dapat dilakukan pada wilayah perparkiran (parking area), atap bangunan atau ru-mah, bentang lahan dan sebagainya. Sistem panen hujan bukan saja cocok dan berpeluang untuk dikembangkan di wilayah ber-iklim kering. Di Indonesia yang beriklim basah sangat berpe-luang untuk melakukan panen hujan. Pada suatu lahan dapat di-rancang sistem panen hujan baik untuk tempat yang merupakan kawasan dataran tinggi (high point), demikian juga dengan kawa-san dataran lebih rendah (low points). Kawasan lebih rendah da-pat dijadikan areal yang dapat dijadikan wilayah yang akan diberi irigasi atau dibangun sub-sistem penampungan air hujan yang berasal dari kawasan tinggi dan atap. Kawasan berlereng serupa dengan kawasan atap bangunan yang dapat digunakan untuk me-ngarahkan air hujan ke kawasan penampungan atau holding area (Rahim dan Halim, 2008).

Sumur resapan akan memberikan dampak berkurangnya limpasan permukaan. Air hujan yang jatuh ke atas permukaan genteng tidak langsung mengalir ke selokan atau halaman rumah tetapi dialirkan melalui seng terus ditampung kedalam sumur re-sapan. Akibat yang bisa dirasakan adalah air hujan tidak menye-bar ke halaman atau selokan sehingga akan mengurangi terjadi-nya limpasan permukaan (Indriatmoko, 1999). Selain itu, United State Environmental Protection agency (2009) mengadakan penelitian atap hijau untuk mengelola limpasan permukaan, di-mana membandingkan kuantitas dan kualitas air dari limpasan permukaan dari atap hijau dengan atap datar dari aspal. Hasilnya menyatakan bahwa atap hijau mampu memindahkan $50 \%$ dari volume air hujan tahunan dari atap melalui penyimpanan dan evapotranspirasi. Air hujan yang disimpan oleh atap hijau diham-bat laju alirannya melalui penambahan waktu untuk mencapai puncak aliran secara efektif dan memperlambat aliran puncak air hujan ke badan air. Penelitian ini belum mempelajari pengaruh jenis tanaman terhadap volume dan laju limpasan permukaan.

Sibarani dan Bambang (2009) mengadakan penelitian lu-bang resapan biopori untuk menentukan laju resap air berdasar-kan variasi umur dan jenis sampah. Dari penelitian tersebut di-dapatkan bahwa jenis sampah kulit buah dengan umur sampah 14 hari lebih besar dalam meresapkan limpasan permukaan dengan laju 
resap air sebesar $1,463 \quad$ x $10^{-4} \quad 1 / \mathrm{dt} / \mathrm{cm}^{2}$. Karakteristik dan muka air tanah dalam hal ini sangat berpengaruh besar atas hasil kinerja lubang resapan biopori.

Berdasarkan hasil dan banyaknya konsep dalam upaya me-lakukan pengendalian limpasan dari beberapa peneliti diatas, ma-ka diperlukan teknik mitigasi limpasan permukaan untuk meminimalisir permasalahan banjir di Kota Palembang. Selanjutnya penelitian ini bertujuan untuk mempelajari teknik-teknik mitigasi limpasan permukaan pada 2 (dua) tipologi penggunaan lahan.

\section{METODE PENELITIAN}

Penelitian tahap ini dilakukan dengan menggunakan studi literatur, survei lapangan, dan eksperimen percobaan hujan buat-an (rainfall simulator) di Laboratorium. Penelitian ini telah di-lakukan dengan percobaan hujan buatan (rainfall simulator) yang disajikan sebagai bagian dari modifikasi rancangan hujan buatan yang dilakukan oleh Rahim (2003) tentang modifikasi hujan buatan. Percobaan hujan buatan dirancang dengan merujuk bebe-rapa literatur dan arahan dari penelitian lainnya.

\section{Perancangan Hujan Buatan}

Percobaan hujan buatan dirangkai dengan menggunakan bahan-bahan sederhana, terdiri dari: 12 alat penyemprot air (nozz-le), pipa PVC 0,5 inchi, satu buah pompa air, satu buah meteran air untuk mengetahu debit pengaliran, sumber air dari kolam se-hingga debit air dibuat konstan, satu buah rumah percobaan, dan satu buah tampungan air limpasan permukaan yang dipasang di bagian depan rumah percobaan. Luas lahan untuk percobaan a-dalah $20 \mathrm{~m}^{2}$ (namun karena proses penataan lokasi, sehingga luas bersih lokasi rancangan menjadi $17,86 \mathrm{~m}^{2}$ ). Lihat Gambar-1 foto lokasi percobaan, Gambar-2 pengukuran curah hujan pada lokasi percobaan, dan Gambar-3 denah rancangan hujan percobaan de-ngan jumlah hujan titik (point of rainfall) uji coba sebanyak 12 titik. Selanjutnya dilakukan percobaan hujan buatan melalui sis-tem aliran konstan selama 1 jam untuk setiap percobaannya dan kemudian hasilnya dirata-rata sebagai hujan wilayah (area rain-fall). Hujan daerah inilah yang dipakai sebagai standar untuk me-ngukur limpasan yang terjadi.

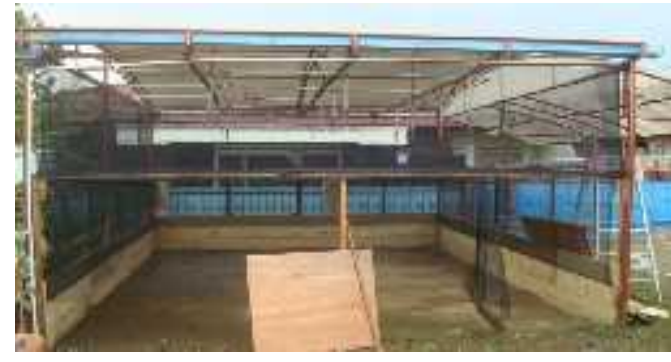

Gambar 1. Lokasi percobaan

\section{Pemakaian Curah hujan dan debit rencana}

Debit air masuk direncanakan sebesar 1 $\mathrm{m}^{3} / \mathrm{jam}$ dengan cu-rah hujan rencana $50 \mathrm{~mm} / \mathrm{jam}$. Curah hujan tersebut sudah terma-suk sangat lebat berdasarkan kriteria intensitas curah hujan dari Badan Meteorologi, Klimatologi dan Geofisika (BMKG). Hasil pengukuran curah hujan di Laboratorium dalam satu jam diper-oleh intensitas curah hujan rerata sebesar $62,54 \mathrm{~mm}$ atau $0,06254 \mathrm{~m}$ (sudah diatas rencana) sehingga diperoleh volume air hujan sebesar $1,11698 \mathrm{~m}^{3}$. Volume air dalam satu jam juga dihitung menggunakan meteran air dengan empat ulangan diperoleh nilai $1,1428 \mathrm{~m}^{3}$ (sudah di atas rencana), sehingga perbedaan volume air masuk dengan volume air hujan $\left(1,1428 \mathrm{~m}^{3}-1,11698 \mathrm{~m}^{3}\right)$ sebesar $0,02582 \mathrm{~m}^{3}$ atau 25,82 liter. Dengan demikian persentase selisih antara volume air masuk dikurangi volume air hujan dengan volume air hujan didapat $\left(\left[0,02582 \mathrm{~m}^{3} / 1,11698\right.\right.$ $\left.\mathrm{m}^{3}\right] \mathrm{x} 100 \%$ ) sebesar $2,31 \%$. Oleh karena persentase selisih yang kecil $(2,31 \%)$, maka volume air yang diambil adalah volume air hujan yaitu $1,11698 \mathrm{~m}^{3}$.

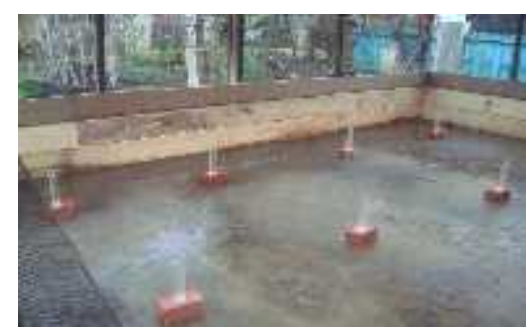

Gambar 2. Pengukuran curah hujan

\section{Rancangan Perlakuan Pada Lahan Percobaan}

Perlakuan dengan empat teknik mitigasi, yaitu sistem panen hujan, sumur resapan, lubang resapan biopori dan atap hijau dite-rapkan pada tipologi penggunaan lahan kawasan permukiman dan perdagangan-jasa. Percobaan hujan buatan dengan parameter yang diamati yaitu volume limpasan yang mengalir ke tampung-an dan 
perlakuan teknik mitigasi untuk tiap tipologi penggunaan lahan dengan tiga ulangan.

a. Untuk rancangan teknik Mitigasi pada permukiman:
1. $\mathbf{M}_{0}=$ Kontrol lahan kosong
2. $\mathrm{M}_{1}=$ Panen Hujan
3. $\mathrm{M}_{2}=$ Sumur Resapan

4. $\mathrm{M}_{4}=$ Lubang Resapan Biopori

b. Untuk rancangan teknik Mitigasi kawasan pada Perdagangan-Jasa:
1. $\mathrm{M}_{0}=$ Kontrol lahan kosong
2. $\mathrm{M}_{1}=$ Panen Hujan
3. $\mathbf{M}_{2}=$ Sumur Resapan
4. $\mathrm{M}_{3}=$ Atap Hijau

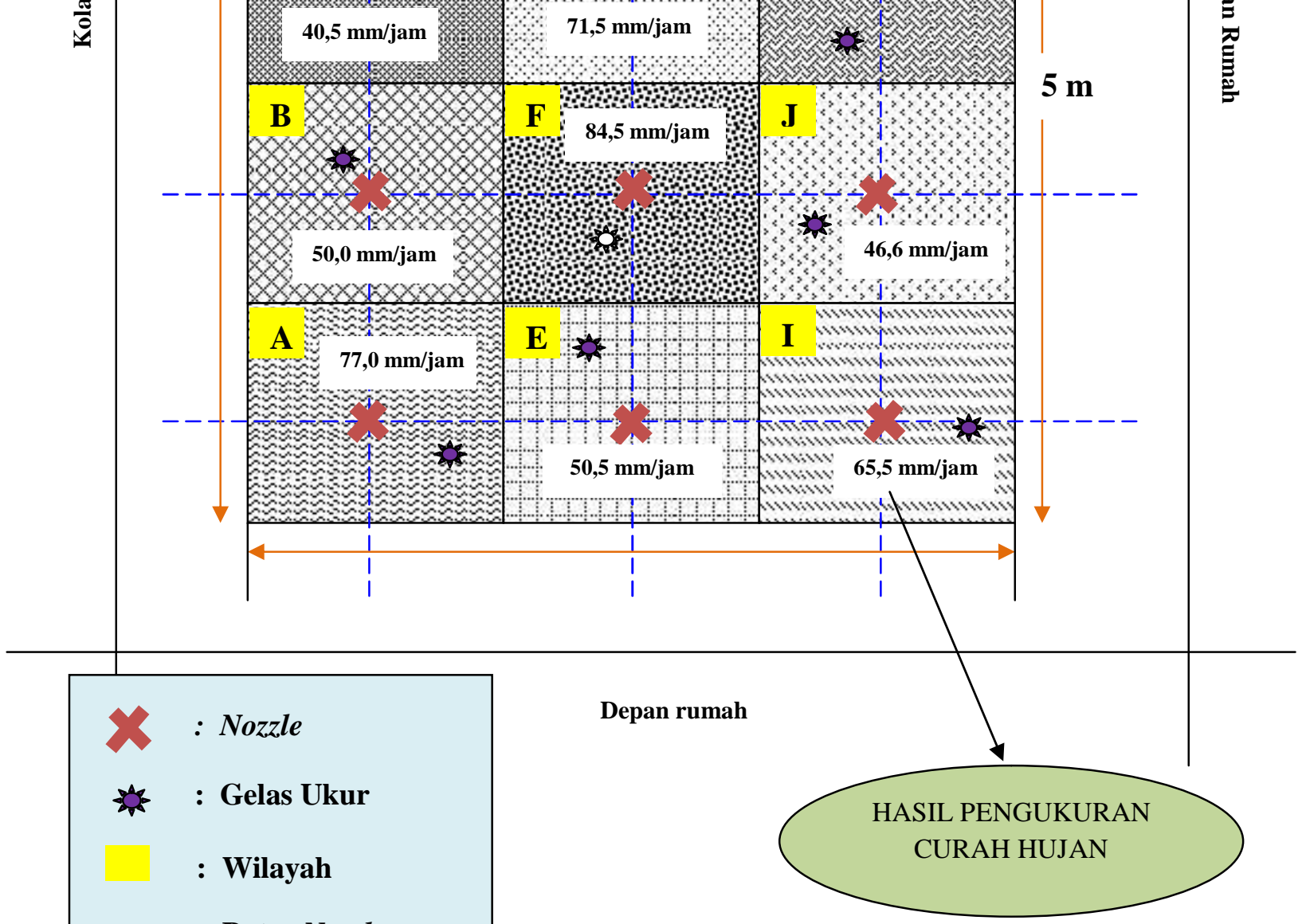

Gambar 3. Denah Rancangan Hujan Percobaan 

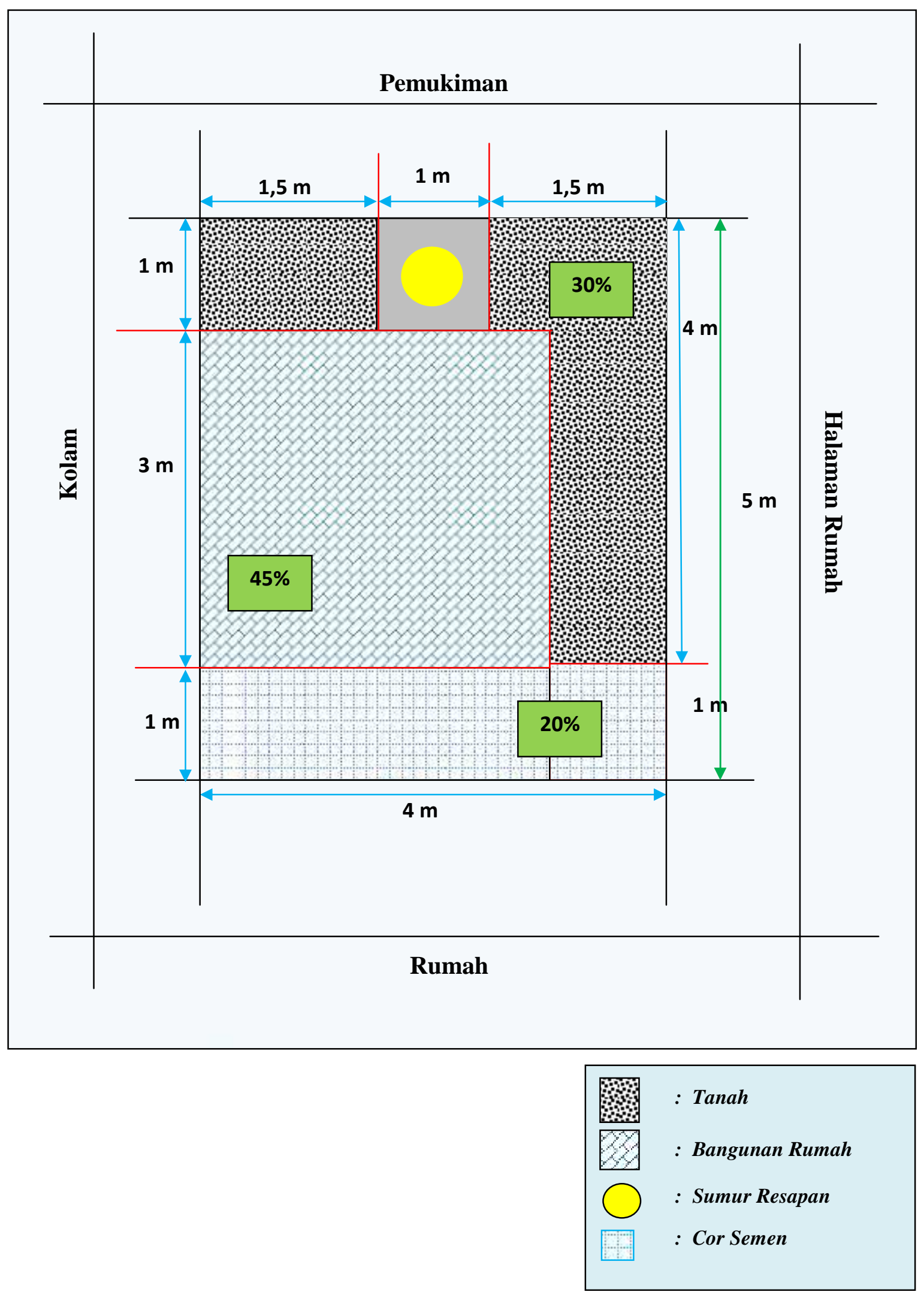

Luas Pemukiman $=15 \mathrm{~m} \times 12 \mathrm{~m}=180 \mathrm{~m}^{2}=1.800 .000 \mathrm{~cm}$

Luas ukuran konversi pemukiman $=5 \mathrm{~m} \times 4 \mathrm{~m}=20 \mathrm{~m}^{2}=200.000 \mathrm{~cm}$

Jadi, Perbandingan Skala $=20 \mathrm{~m}^{2}: 180 \mathrm{~m}^{2}=200.000 \mathrm{~cm}: 1.800 .000 \mathrm{~cm}=1: 9$

Volume Sumur Resapan $=3,6 \mathrm{~m}^{3}: 9=0,4 \mathrm{~m}^{3}$

\section{Gambar 4. Denah Rancangan Percobaan Pada Kondisi Pemukiman}




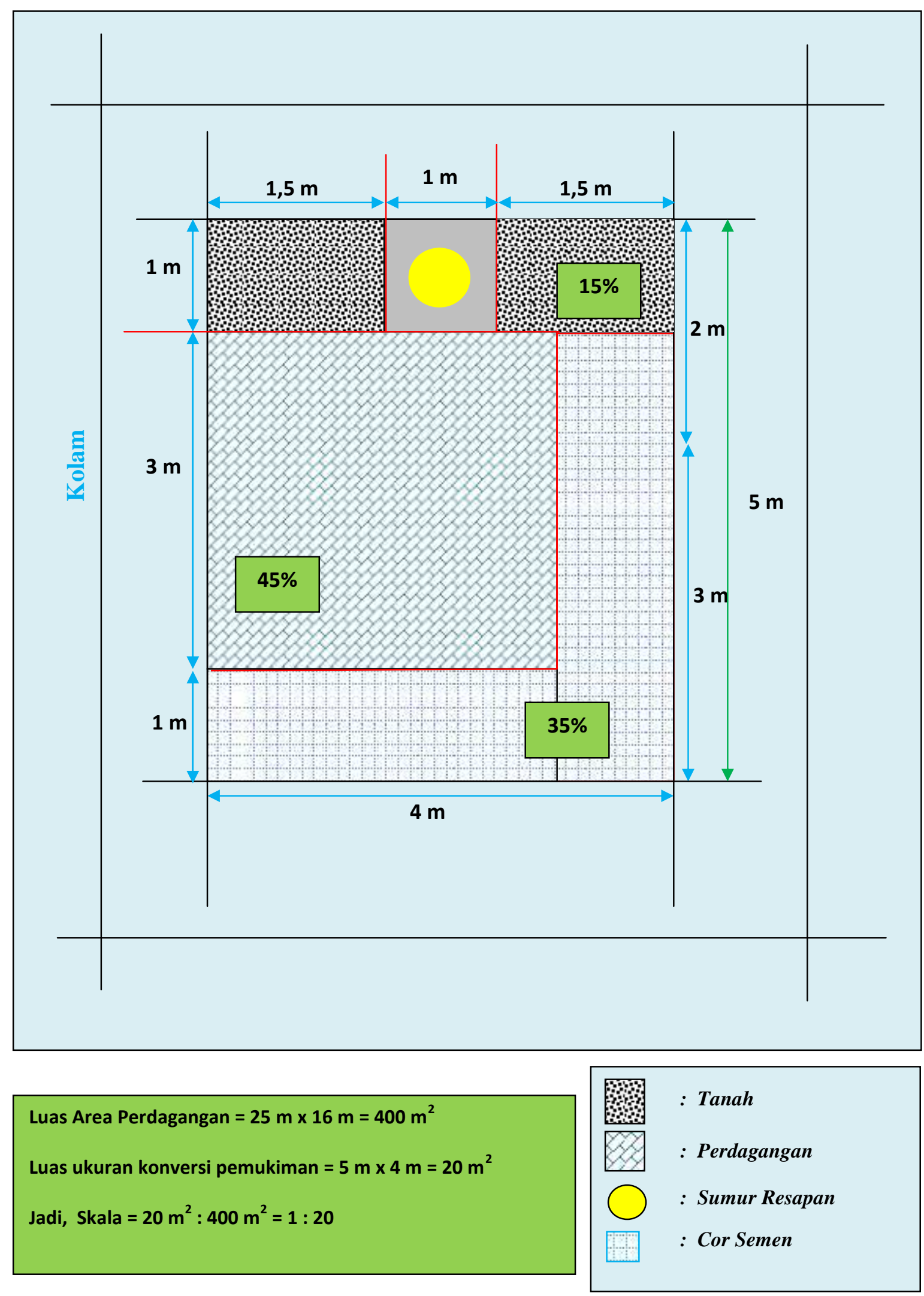

Gambar 5. Denah Rancangan Percobaan Pada Kondisi Pertokoan 


\section{Rancangan Teknik Mitigasi}

\section{1) Kondisi Lahan Sebenarnya berdasarkan survei lapangan.}

Berdasarkan hasil rata-rata dari survei lapangan, terdapat lahan eksisting (permukiman dan perdagangan-jasa) dengan luas $120 \mathrm{~m}^{2}$ sampai dengan $300 \mathrm{~m}^{2}$ dengan kondisi tutupan bangunan sekitar $45 \%$ dari total luas lahan, digunakan sebagai perbanding-an untuk rancangan percobaan, denah rancangan percobaan untuk kondisi pemukiman dapat dilihat pada Gambar 4. Selain itu, tek-nik mitigasi sumur resapan, panen hujan dan biopori diterapkan pada lahan permukiman dan untuk lahan perdagangan-jasa dite-rapkan teknik mitigasi sumur resapan, panen hujan dan atap hijau. Selanjutnya perencanaan dimensi teknik mitigasi pada lahan seluas $400 \mathrm{~m}^{2}$ dengan skala geometrik 1 : 5 disajikan dalam Tabel 1 . Sedangkan untuk rancangan percobaan disajikan dalam Tabel 2.

Tabel 1. Dimensi Teknik Mitigasi dalam Ukuran

\begin{tabular}{|c|c|c|c|c|}
\hline $\begin{array}{l}\text { Jenis } \\
\text { Mitigasi }\end{array}$ & $\begin{array}{l}\text { Diameter } \\
(\mathbf{m})\end{array}$ & $\begin{array}{c}\text { Panjang } \\
\text { (m) }\end{array}$ & $\begin{array}{c}\text { Ke- } \\
\text { dalaman } \\
(\mathbf{m})\end{array}$ & Keterangan \\
\hline $\begin{array}{l}\text { Sumur } \\
\text { resapan }\end{array}$ & 0,70 & 2,50 & 1,50 & $\begin{array}{l}\text { Bagian bawah } \\
\text { sumur diberi } \\
\text { campuran pasir } \\
\text { dan kerikil } \\
\text { untuk } \\
\text { mempercepat } \\
\text { peresapan air. }\end{array}$ \\
\hline $\begin{array}{l}\text { Panen } \\
\text { Hujan }\end{array}$ & 0,70 & 2,50 & 1,50 & $\begin{array}{l}\text { Bagian bawah } \\
\text { kedap air } \\
\text { sehingga air } \\
\text { bisa } \\
\text { dimanfaatkan. }\end{array}$ \\
\hline Biopori & 0,2 & - & 1,00 & $\begin{array}{l}\text { Jumlah lubang } \\
\text { sebanyak } 30 \\
\text { lubang dengan } \\
\text { jarak antar } \\
\text { lubang } 2 \mathrm{~m} \text {. }\end{array}$ \\
\hline $\begin{array}{l}\text { Atap } \\
\text { Hijau }\end{array}$ & - & - & $\begin{array}{c}0,05- \\
0,15\end{array}$ & $\begin{array}{l}\text { Luasan } \\
\text { penggunaan } \\
\text { disesuaikan } \\
\text { dengan luasan } \\
\text { atap dan jenis } \\
\text { vegetasi } \\
\text { disesuaikan dgn } \\
\text { ketahanan } \\
\text { bangunan dan } \\
\text { kemampuan } \\
\text { tumbuh. }\end{array}$ \\
\hline
\end{tabular}

Sumber: Hasil Kajian Berbagai Literatur, 2017
Keterangan: Jumlah Lubang Biopori $=$ (intensitas hujan $\mathrm{x}$ luas bidang kedap) : laju peresapan air perlubang.

\section{2) Kondisi Modifikasi Pada Lahan Percobaan}

Lahan percobaan dengan ukuran $4 \mathrm{~m}$ x $5 \mathrm{~m}$ $=20 \mathrm{~m}^{2}$ dijadikan model pada lahan dengan ukuran $4,7 \mathrm{~m} \times 3,8 \mathrm{~m}=17,86 \mathrm{~m}^{2}$, sehingga didapatkan skala geometrik antara model dengan la-han adalah 1 : 5. Sehingga ukuran dimensi terlihat dalam tabel 2. Selain itu, untuk teknik mitigasi atap hijau dengan ketebalan ta-nah $7,5 \mathrm{~cm}$ diterapkan pada lahan perdagangan-jasa dengan kon-disi luasan bangunan $45 \%$ dari total luas lahan, sehingga luas ba-ngunan $7,1 \mathrm{~m}^{2}$. Adapun denah rancangan percobaan untuk kondisi lahan perdangan-jasa dapat dilihat pada Gambar 5.

Tabel 2. Dimensi Teknik Mitigasi dalam Rancang Percobaan

\begin{tabular}{|c|c|c|c|c|}
\hline $\begin{array}{c}\text { Jenis } \\
\text { Mitigasi }\end{array}$ & $\begin{array}{l}\text { Diameter } \\
\text { (m) }\end{array}$ & $\begin{array}{c}\text { Panjang } \\
\text { (m) }\end{array}$ & $\begin{array}{c}\text { Ke- } \\
\text { dalaman } \\
(\mathbf{m})\end{array}$ & Keterangan \\
\hline $\begin{array}{l}\text { Sumur } \\
\text { resapan }\end{array}$ & 0,14 & 0,5 & 0,3 & $\begin{array}{l}\text { Bagian } \\
\text { bawah sumur } \\
\text { diberi } \\
\text { campuran } \\
\text { pasir dan } \\
\text { kerikil untuk } \\
\text { mempercepat } \\
\text { peresapan } \\
\text { air. }\end{array}$ \\
\hline $\begin{array}{l}\text { Panen } \\
\text { Hujan }\end{array}$ & 0,14 & 0,5 & 0,3 & $\begin{array}{l}\text { Bagian } \\
\text { bawah } \\
\text { ditutup } \\
\text { lapisan } \\
\text { plastik } \\
\text { sehingga air } \\
\text { tidak keluar. }\end{array}$ \\
\hline Biopori & 0,04 & - & 0,2 & $\begin{array}{l}\text { Jumlah } \\
\text { lubang } \\
\text { sebanyak } 30 \\
\text { lubang dgn } \\
\text { jarak antar } \\
\text { lubang } 0,4 \\
\text { m. }\end{array}$ \\
\hline $\begin{array}{l}\text { Atap } \\
\text { Hijau }\end{array}$ & - & - & 0,075 & $\begin{array}{l}\text { Luasan } \\
\text { penggunaan } \\
\text { disesuaikan } \\
\text { luasan atap } \\
\text { dan jenis } \\
\text { vegetasi } \\
\text { digunakan } \\
\text { rumput. }\end{array}$ \\
\hline
\end{tabular}

Sumber: Rancangan Teknik Mitigasi, 2017. 


\section{HASIL DAN PEMBAHASAN}

\section{Penentuan teknik mitigasi pada tiga tipologi penggunaan lahan}

Pemilihan teknik mitigasi limpasan permukaan yang digu-nakan berdasarkan kesesuaian pada tipologi penggunaan lahan. Walaupun demikian, belum ada satu jenis teknik mitigasi yang dapat menyelesaikan semua masalah limpasan permukaan. Setiap jenis teknik memiliki keterbatasan berdasarkan volume limpasan permukaan yang dikelola, ketersediaan lahan, jenis tanah, kemi-ringan lahan, dan kedalaman muka air tanah. Selain itu, pertimbangan yang teliti untuk pemilihan teknik mitigasi adalah penting sesuai dengan jenis lahan yang ada.

Hasil dari studi literatur terhadap beberapa jenis teknik mi-tigasi limpasan permukaan pada tipologi penggunaan lahan disa-jikan dalam Tabel 3.

Selanjutnya dari Tabel 3 menggambarkan bentuk dan kese-suaian teknik yang digunakan untuk percobaan pada beberapa ti-pologi penggunaan lahan, dengan pertimbangan kondisi atau fak-tor yang mempengaruhi limpasan permukaan, yaitu berdasarkan bentuk atau objek fisik jenis penutupan lahan (vegetasi dan tutup-an lainnya), jenis tanah, tekstur tanah, kemiringan lahan dan ter-masuk kemampuan meresapkan/meloloskan air (permeabilitasinfiltrasi).

\section{Perlakuan Teknik Mitigasi pada Permukiman dan Perdagangan-jasa}

Pengaruh teknik mitigasi limpasan permukaan secara indi-vidu pada dua tipologi lahan ditampilkan pada tabel 4 berikut.

Tabel 3. Penyesuaian Teknik Mitigasi

Limpasan Permukaan Pada Penggunaan Lahan

\begin{tabular}{|c|c|c|c|}
\hline No & $\begin{array}{c}\text { Tipologi } \\
\text { Penggunaan } \\
\text { Lahan } \\
\end{array}$ & $\begin{array}{l}\text { Pengendalian } \\
\text { Limpasan } \\
\text { Permukaan } \\
\end{array}$ & $\begin{array}{c}\text { Alasan Kesesuaian } \\
\text { atau Ketidaksesuaian } \\
\text { untuk Penerapannya }\end{array}$ \\
\hline 1 & $\begin{array}{l}\text { Perdagangan- } \\
\text { Jasa }\end{array}$ & Atap Hijau & $\begin{array}{l}\text { Bisa diterapkan karena } \\
\text { terdapat banyak } \\
\text { bangunan dengan atap } \\
\text { beton dan datar sehingga } \\
\text { mampu menahan beban } \\
\text { tanah dan tanaman di } \\
\text { atasnya. }\end{array}$ \\
\hline
\end{tabular}

Lubang Tidak bisa diterapkan

\begin{tabular}{|c|c|c|c|}
\hline & & $\begin{array}{l}\text { Resapan } \\
\text { Biopori }\end{array}$ & $\begin{array}{l}\text { karena ruang terbuka } \\
\text { banyak tertutup } \\
\text { bangunan dan lahan } \\
\text { parkir umumnya } \\
\text { tertutup dengan lapisan } \\
\text { semen. }\end{array}$ \\
\hline & & $\begin{array}{l}\text { Sumur } \\
\text { Resapan }\end{array}$ & $\begin{array}{l}\text { Bisa diterapkan karena } \\
\text { hanya membutuhkan - } \\
\text { tempat yang kecil di } \\
\text { dekat saluran air (tidak } \\
\text { membutuhkan lahan } \\
\text { yang luas). }\end{array}$ \\
\hline & & Panen Hujan & $\begin{array}{l}\text { Bisa diterapkan karena } \\
\text { terdapat banyak } \\
\text { bangunan dengan atap } \\
\text { beton dan datar sehingga } \\
\text { air hujan yang mengalir } \\
\text { dari atap dapat } \\
\text { ditampung pada tangki } \\
\text { air. }\end{array}$ \\
\hline 2 & Permukiman & Atap Hijau & $\begin{array}{l}\text { Tidak bisa diterapkan } \\
\text { pada bangunan } \\
\text { perumahan karena atap } \\
\text { genteng atau seng } \\
\text { umumnya tidak } \\
\text { dirancang untuk dapat } \\
\text { menahan tanah dan } \\
\text { tanaman. Bangunan } \\
\text { pemukiman juga } \\
\text { memiliki tingkat } \\
\text { kemiringan yang tinggi } \\
\text { sehingga sulit dan mahal } \\
\text { dalam penerapan } \\
\text { konstruksi atap hijau. }\end{array}$ \\
\hline & & $\begin{array}{l}\text { Lubang } \\
\text { Resapan } \\
\text { Biopori }\end{array}$ & $\begin{array}{l}\text { Bisa diterapkan pada } \\
\text { pekarangan rumah atau } \\
\text { ruang terbuka lainnya di } \\
\text { lingkungan permukiman } \\
\text { karena pada lahan } \\
\text { pemukiman umumnya } \\
\text { masih terdapat lahan } \\
\text { kosong. }\end{array}$ \\
\hline & & $\begin{array}{l}\text { Sumur } \\
\text { Resapan }\end{array}$ & $\begin{array}{l}\text { Bisa diterapkan pada } \\
\text { setiap rumah karena } \\
\text { tidak membutuhkan } \\
\text { lahan yang luas atau } \\
\text { dibuat sumur resapan } \\
\text { kolektif pada } \\
\text { lingkungan perumahan } \\
\text { berupa kolam retensi. }\end{array}$ \\
\hline & & Panen Hujan & $\begin{array}{l}\text { Bisa diterapkan pada } \\
\text { bangunan dengan atap } \\
\text { seng atau genteng dan } \\
\text { air hujan yang mengalir } \\
\text { dari atap dapat } \\
\text { ditampung pada tangki } \\
\text { air. }\end{array}$ \\
\hline
\end{tabular}

Sumber: Analisis berbagai literatur, 2017. 
Tabel 4. Rata-rata Volume Limpasan permukaan dari percobaan

\begin{tabular}{cc}
\hline $\begin{array}{c}\text { Perlakuan } \\
\text { (Teknik mitigasi) }\end{array}$ & $\begin{array}{c}\text { Rata-rata Volume } \\
\text { Limpasan Permukaan } \\
\text { (liter) }\end{array}$ \\
\hline \multicolumn{2}{c}{ Pemukiman $\left(\mathrm{L}_{1}\right)$} \\
\hline $\mathrm{M}_{0}$ (Lokal Kontrol) \\
$\mathrm{M}_{1}$ (Panen Hujan) \\
$\mathrm{M}_{2}$ (Sumur Resapan) \\
$\mathrm{M}_{4}$ (Biopori) & 380,33 \\
\hline \multicolumn{1}{c}{ Perdagangan \& Jasa $\left(L_{2}\right)$} \\
\hline $\mathrm{M}_{0}$ (Lokal Kontrol) & 368,67 \\
$\mathrm{M}_{1}$ (Panen Hujan) & 743,67 \\
$\mathrm{M}_{2}$ (Sumur Resapan) & 459,33 \\
$\mathrm{M}_{3}$ (Atap Hijau) & 428,67 \\
\hline
\end{tabular}

Sumber: Hasil percobaan lapangan, 2017

Dari tabel tersebut diperoleh hasil yang berbeda dari tiap penggunaan lahan. Berdasarkan rataan volume limpasan permu-kaan yang diperoleh dari tiga kali ulangan menunjukan bahwa untuk lahan permukiman didapat teknik mitigasi lubang resapan biopori yang paling besar memitigasi limpasan permukaan yaitu sebesar 338,33 liter atau sebesar 54,71 \% dari kontrol lahan ko-song tanpa teknik mitigasi. Sedangkan untuk lahan perdagangan-jasa diketahui teknik mitigasi sumur resapan paling besar memi-tigasi limpasan sebesar 428,67 liter atau 42,35\% dari kontrol la-han kosong tanpa teknik mitigasi. Dengan demikian teknik miti-gasi telah menurunkan volume limpasan permukaan hampir $50 \%$ untuk kedua jenis penggunaan lahan tersebut.

Selanjutnya dalam Gambar 6 dan Gambar 7, dijelaskan bahwa terjadi pengaruh teknik mitigasi terhadap rerata volume limpasan permukaan pada lahan permukiman dan perdagangan-jasa, dimana hal ini disebabkan adanya perbedaan penutupan la-han. Penutupan lahan di lahan perdaganganjasa sebagian besar $(85 \%)$ sebagai lahan kedap air (bangunan dan cor semen), sisa-nya berupa tanah terbuka sebesar $15 \%$.

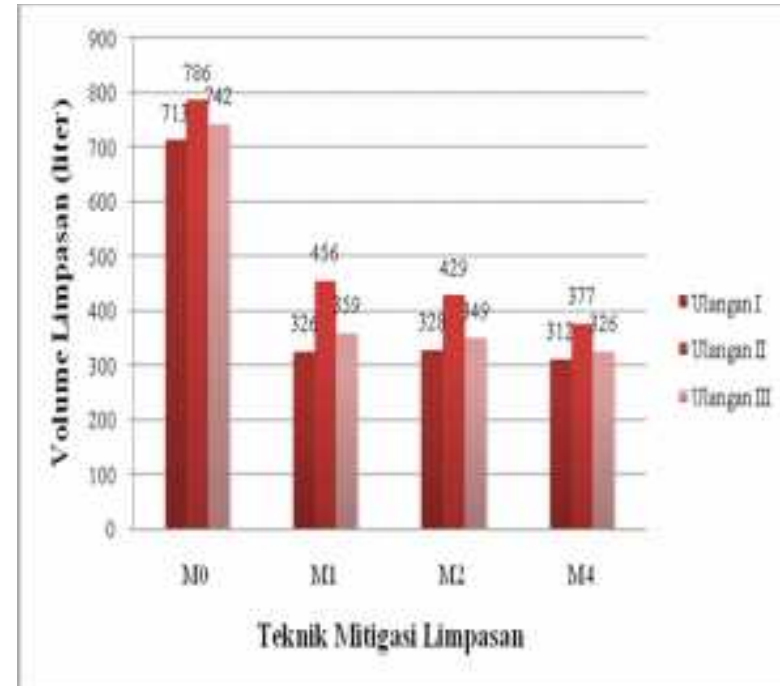

Gambar 6. Hubungan Pengaruh Teknik Mitigasi terhadap Rataan Volume Limpasan Permukaan pada Lahan Pemukiman

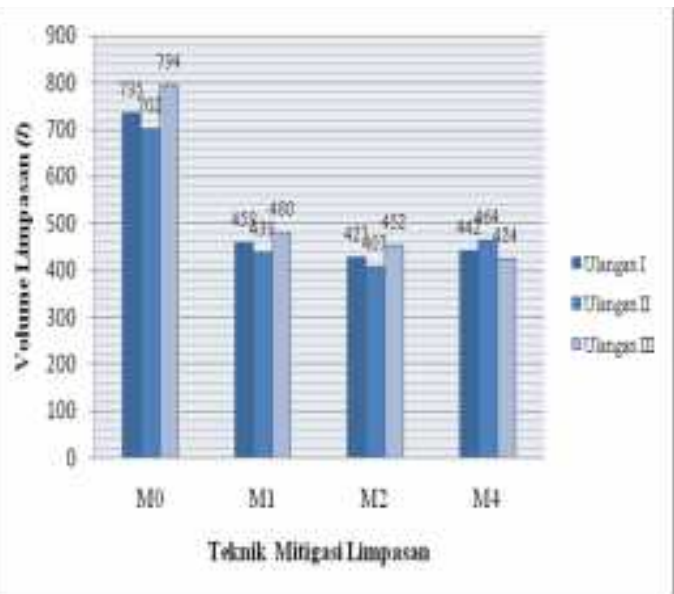

Gambar 7. Hubungan Pengaruh Teknik Mitigasi terhadap Rataan Volume Limpasan Permukaan pada Lahan Perdagangan-Jasa

Sedangkan untuk penutupan lahan di pemukiman berupa $60 \%$ lahan kedap air (bangunan dan cor semen), 25\% lahan ter-buka dan $15 \%$ vegetasi/rumput (lihal lampiran denah penutupan lahan permukiman dan perdaganganjasa). Adanya vegetasi (rumput) pada lahan pemukiman sebagai penutupan lahan secara efektif mampu mengabsorbsi air hujan, mempertahankan laju in-filtrasi (Foth, 1984). Nilai Kapasitas Retensi Air (KRA) lahan bervegetasi lebih besar dibanding lahan tidak bervegetasi (Agus, 2004). Selanjutnya untuk mengetahui besarnya pengaruh peng-ujian teknik mitigasi terhadap dua tipologi penggunaan lahan permukiman dan perdagangan-jasa ditampilkan pada Tabel 5 berikut ini. 
Pada Tabel 5 diperoleh hubungan pengaruh dari bentuk teknik mitigasi untuk kedua jenis tipologi lahan adalah berbeda nyata pada taraf 1\%. Hal ini berarti perlakuan teknik mitigasi terhadap volume limpasan permukaan berpengaruh sangat nyata terhadap lahan pemukiman $\left(\mathrm{L}_{1}\right)$ dan perdagangan-jasa $\left(\mathrm{L}_{2}\right)$. Dengan demikian, teknik mitigasi yang dilakukan pada tiap peng-gunaan lahan telah memberikan perubahan terhadap volume lim-pasan permukaan. Dengan demikian sistem panen hujan, sumur resapan, atap hijau, dan lubang resapan lubang resapan biopori dapat digunakan sebagai alternatif dalam mitigasi limpasan permukaan.

Selanjutnya dari data tersebut dilakukan pengujian terhadap gabungan dari teknik mitigasi yang dilakukan terhadap tipologi lahan untuk mengetahui hubungan dan pengaruh terhadap potensi limpasan yang terjadi. Hal tersebut disajikan dalam tabel 6.
Sedangkan pada Tabel 6 menunjukan berdasarkan hasil analisa secara gabungan bahwa teknik mitigasi berpengaruh sa-ngat nyata terhadap volume limpasan permukaan pada kedua penggunaan lahan (pemukiman dan perdagangan-jasa). Dari hasil analisa tersebut dapat disimpulkan perlakuan teknik mitigasi dapat diterapkan pada kedua jenis penggunaan lahan.

Berdasarkan Tabel 7, menunjukan bahwa pada lahan per-mukiman respon $\mathrm{K}_{1}$ sebagai Lokal kontrol $\left(\mathrm{M}_{0}\right)$ terhadap kom-binasi perlakuan teknik mitigasi $\left(\mathrm{M}_{1}, \mathrm{M}_{2}\right.$, dan $\left.\mathrm{M}_{4}\right)$, memberikan pengaruh yang berbeda nyata terhadap volume limpasan permu-kaan. Hal ini berarti bahwa perlakuan teknik mitigasi menyebab-kan terjadi perbedaan volume limpasan permukaan, walaupun untuk K2 dan K3 tidak berbeda nyata yang berarti tidak ada perlakuan teknik mitigasi yang dominan satu sama lainnya.

Tabel 5. Hasil Analisis Sidik Ragam (uji F) IndividuTeknik Mitigasi terhadapLahan Permukiman dan Perdagangan-Jasa

\begin{tabular}{|c|c|c|c|c|c|c|}
\hline \multirow{2}{*}{$\begin{array}{c}\text { Sumber } \\
\text { keragaman } \\
(\mathrm{SK})\end{array}$} & \multirow{2}{*}{$\begin{array}{c}\text { Derajat } \\
\text { Bebas } \\
\text { (DB) }\end{array}$} & \multirow{2}{*}{$\begin{array}{c}\text { Jumlah } \\
\text { Kuadrat } \\
\text { (JK) }\end{array}$} & \multirow{2}{*}{$\begin{array}{c}\text { Kuadrat } \\
\text { Tengah (KT) }\end{array}$} & \multirow{2}{*}{ F-Hitung } & \multicolumn{2}{|c|}{ F- Tabel } \\
\hline & & & & & $\mathbf{0 , 0 5}$ & $\mathbf{0 , 0 1}$ \\
\hline \multicolumn{7}{|c|}{ Pemukiman (L1) } \\
\hline Ulangan & 2 & 18296,17 & 9148,08 & & & \\
\hline Teknik Mitigasi & 3 & 335556,92 & 111852,31 & $430,25^{* *}$ & 4,76 & 9,78 \\
\hline galat & 6 & 1559,8333 & 259,97 & & & \\
\hline \multicolumn{7}{|c|}{ Perdagangan \& Jasa (L2) } \\
\hline Ulangan & 2 & 2434,5 & 1217,25 & & & \\
\hline Teknik Mitigasi & 3 & 203761,58 & 67920,53 & $89,17^{* *}$ & 4,76 & 9,78 \\
\hline galat & 6 & 4570,1667 & 761,69 & & & \\
\hline
\end{tabular}

Tabel 6. Hasil Analisis Sidik Ragam (uji F) Gabungan dari Teknik Mitigasi terhadap Lahan Permukiman dan Perdagangan-Jasa

\begin{tabular}{|c|c|c|c|c|c|c|}
\hline \multirow{2}{*}{$\begin{array}{c}\text { Sumber keragaman } \\
\text { (SK) }\end{array}$} & \multirow{2}{*}{$\begin{array}{c}\text { Derajat } \\
\text { Bebas } \\
\text { (DB) }\end{array}$} & \multirow{2}{*}{$\begin{array}{c}\text { Jumlah } \\
\text { Kuadrat } \\
\text { (JK) }\end{array}$} & \multirow{2}{*}{$\begin{array}{c}\text { Kuadrat } \\
\text { Tengah } \\
\text { (KT) }\end{array}$} & \multirow{2}{*}{ F-Hitung } & \multicolumn{2}{|c|}{ F- Tabel } \\
\hline & & & & & 0,05 & $\mathbf{0 , 0 1}$ \\
\hline Lahan (L) & 1 & 21720,17 & 21720,17 & & & \\
\hline Ulangan (r) dalam & 4 & & & & & \\
\hline lahan & & 20730,67 & 5182,67 & & & \\
\hline $\begin{array}{l}\text { Teknik Mitigasi (p) } \\
\text { dalam lahan }\end{array}$ & 6 & 539318,5 & 89886,42 & $175,96^{* *}$ & 3,00 & 4,82 \\
\hline Galat Gabungan & 12 & 6130 & 510,83 & & & \\
\hline Umum & 23 & 201755,27 & & & & \\
\hline
\end{tabular}

Sedangkan untuk lahan perdagangan-jasa respon $\mathrm{K}_{1}$ seba-gai Lokal kontrol $\left(\mathrm{M}_{0}\right)$ terhadap kombinasi perlakuan teknik miti-gasi $\left(\mathrm{M}_{1}, \mathrm{M}_{2}\right.$, dan $\mathrm{M}_{3}$ ), memberikan pengaruh yang berbeda 
nya-ta terhadap volume limpasan permukaan. Hal ini berarti adanya perlakuan teknik mitigasi menyebabkan terjadi perbedaan volu-me limpasan permukaan, walaupun untuk K2 dan K3 tidak ber-beda nyata yang berarti tidak ada perlakuan teknik mitigasi yang dominan satu sama lainnya.

Dilihat dari kedua penjelasan tersebut dapat diprediksikan bahwa faktor yang menyebabkan tidak adanya teknik mitigasi le-bih dominan daripada yang lainnya disebabkan karena intensitas curah hujan buatan yang diberikan dalam percobaan termasuk kriteria sangat lebat $(62,54 \mathrm{~mm})$ sehingga teknik mitigasi yang ada tidak mampu mengelola air dengan maksimal (terjadinya flooding). Selain itu, jenis tanah yang terkategori mudah jenuh air membuat air yang terserap terbatas dan sisanya menjadi limpasan permukaan. Oleh karena itu perlu dilakukan penelitian lanjutan untuk mengkaji teknik-teknik mitigasi yang dibuat secara kombi-nasi untuk setiap penggunaan lahan, misalnya untuk lahan per-mukiman; teknik panen hujan dengan sumur resapan, panen hu-jan dengan lubang resapan biopori, sumur resapan dengan lubang resapan biopori, dan panen hujan dengan sumur resapan dan lu-bang resapan biopori. Sedangkan lahan perdagangan-jasa meli-puti: teknik panen hujan dengan sumur resapan, panen hujan dengan atap hijau, sumur resapan dengan atap hijau, dan panen hujan dengan sumur resapan dan atap hijau.

Tabel 7. Hasil Uji-F Kontras Teknik Mitigasi terhadap Volume Limpasan yang Mengalir ke Tampungan

\begin{tabular}{|c|c|c|c|c|c|c|}
\hline \multirow{2}{*}{$\begin{array}{l}\text { Sumber Keragaman } \\
\text { (SK) }\end{array}$} & \multirow{2}{*}{$\begin{array}{c}\text { Derajat } \\
\text { Bebas } \\
\text { (DB) }\end{array}$} & \multirow{2}{*}{$\begin{array}{c}\text { Jumlah } \\
\text { Kuadrat } \\
\text { (JK) }\end{array}$} & \multirow{2}{*}{$\begin{array}{c}\text { Kuadrat } \\
\text { Tengah (KT) }\end{array}$} & \multirow{2}{*}{ F-Hitung } & \multicolumn{2}{|c|}{ F Tabel } \\
\hline & & & & & $\mathbf{0 , 0 5}$ & $\mathbf{0 , 0 1}$ \\
\hline Lahan (L) & 1 & 21720 & 21720 & & & \\
\hline $\begin{array}{l}\text { Ulangan }(\mathrm{r}) \text { dalam lahan } \\
\text { Teknik Mitigasi }(\mathrm{p}) \\
\text { dalam lahan }\end{array}$ & 4 & 20730,67 & 5182,67 & $175,96^{* *}$ & 3,00 & 4,82 \\
\hline \multicolumn{7}{|l|}{ Pemukiman (L1) } \\
\hline $\mathrm{K} 1\left(\mathrm{M}_{0}\right.$ vs $\left.\mathrm{M}_{1}, \mathrm{M}_{2}, \mathrm{M}_{4}\right)$ & 1 & 332736,69 & 332736,69 & $651,36 * *$ & 4,75 & 9,33 \\
\hline $\mathrm{K} 2\left(\mathrm{M}_{1} \mathrm{vs} \mathrm{M}_{2}\right)$ & 1 & 204,16667 & 204,17 & $0,40^{\operatorname{tn}}$ & 4,75 & 9,33 \\
\hline $\mathrm{K} 3\left(\mathrm{M}_{2} \mathrm{vs} \mathrm{M}_{4}\right)$ & 1 & 1380,1667 & 1380,17 & $2,70^{\operatorname{tn}}$ & 4,75 & 9,33 \\
\hline \multicolumn{7}{|l|}{ Perdagangan $\left(\mathbf{L}_{2}\right)$} \\
\hline $\mathrm{K} 1\left(\mathrm{M}_{0}\right.$ vs $\left.\mathrm{M} 1, \mathrm{M}_{2}, \mathrm{M}_{3}\right)$ & 1 & 202350,03 & 202350,03 & $396,12^{* * *}$ & 4,75 & 9,33 \\
\hline $\mathrm{K} 2\left(\mathrm{M}_{1} \mathrm{vs} \mathrm{M}_{2}\right)$ & 1 & 1410,6667 & 1410,67 & $2,76^{\mathrm{tn}}$ & 4,75 & 9,33 \\
\hline $\mathrm{K} 3\left(\mathrm{M}_{2}\right.$ vs $\left.\mathrm{M}_{3}\right)$ & 1 & 322,66667 & 322,67 & $0,63^{\mathrm{tn}}$ & 4,75 & 9,33 \\
\hline Galat Gabungan & 12 & 6130 & 510,83333 & & & \\
\hline Umum & 23 & 1126303,6 & & & & \\
\hline
\end{tabular}

\section{KESIMPULAN DAN SARAN}

\section{Kesimpulan}

Teknik mitigasi yang dapat digunakan untuk mengendali-kan limpasan permukaan, diantaranya; sistem panen hujan, sumur resapan, lubang biopori dan atap hijau. Pada lahan permukiman didapat teknik mitigasi lubang biopori yang cenderung paling besar memitigasi limpasan yaitu sebesar 338,33 liter atau sebesar $54,71 \%$ dari kontrol lahan kosong tanpa teknik mitigasi, sedang-kan untuk lahan perdaganganjasa diketahui teknik mitigasi su-mur resapan cenderung paling besar memitigasi limpasan sebesar 428,67 liter atau $42,35 \%$ dari kontrol lahan kosong tanpa teknik mitigasi.

Berdasarkan uji kontras, teknik mitigasi limpasan permuka-an pada lahan permukiman dan perdagangan-jasa menunjukkan tidak adanya perlakuan teknik yang dominan satu sama lainnya, oleh karena itu diprediksi faktor yang menyebabkannya adalah intensitas curah hujan buatan yang diberikan dalam rancang per-cobaan termasuk kriteria sangat lebat $(62,54 \mathrm{~mm})$, sehingga tek-nik mitigasi yang ada tidak mampu mengelola air dengan maksi-mal (terjadinya 
flooding). Selain itu, jenis tanah yang terkategori mudah jenuh air membuat air yang terserap terbatas dan sisanya menjadi limpasan permukaan.

\section{Saran}

Perlunya dilakukan penelitian lanjutan untuk mengkaji teknik-teknik mitigasi yang dibuat secara kombinasi untuk setiap penggunaan lahan, misalnya untuk lahan permukiman; teknik pa-nen hujan dengan sumur resapan, panen hujan dengan lubang re-sapan biopori, sumur resapan dengan lubang resapan biopori, dan panen hujan dengan sumur resapan dan lubang resapan biopori. Sedangkan pada lahan perdagangan-jasa meliputi; teknik panen hujan dengan sumur resapan, panen hujan dengan atap hijau, su-mur resapan dengan atap hijau, dan panen hujan dengan sumur resapan dan atap hijau.

\section{DAFTAR PUSTAKA}

Anonim. (2010). "Pengantar Lubang resapan biopori". (http:// www. lubang resapan biopori.com, diakses tanggal 8 Septem-ber 2010).

Sitanala, Asdak. (2010). Konservasi Tanah dan Air. IPB Press. Bogor.

Brata, Kamir Raziudin. (1992). "Pemanfaatan Jerami Sebagai Mulsa Vertikal Untuk Pengendalian Aliran Permukaan, Erosi Dan Kehilangan Unsur Hara Dari Pertanian Lahan Kering." Laboratorium Fisika dan Konservasi Tanah, Jurusan Tanah, Fakultas Pertanian IPB. Bogor.

Darsono, Suseno. (2007). "Sistem Pengelolaan Air Hujan Yang Ramah Lingkungan." Jurnal Teknik Keairan. Vol. 13 No. 4 Desember 2007.

Dede, Rohmat dan Indiatmo Soekarno. (2004). "Pendugaan Limpasan Hujan Pada Cekungan Kecil Melalui Pengembang-an Persamaan Infiltrasi Kolom Tanah." Makalah PIT HATMI XXI, 2004. Denpasar, Bali.

Gureti, Pamela. (2009). "Studi Efektivitas Sumur Resapan dalam Mengurangi Air Limpasan Hujan: Studi Kasus Kota Sura-baya." Skripsi. Jurusan Teknik Lingkungan Fakultas Teknik Sipil dan Perencanaan Institut Teknologi Sepuluh Nopember. Surabaya.
Haryani, Suryo., Fajar Yulianto dan Anneke. (2008). "Analisis Tingkat Rawan Banjir di Propinsi Jawa Timur Dari Data Penginderaan Jauh dan SIG." Bidang Pemantauan Sumber Daya Alam dan Lingkungan Lembaga Penerbangan dan An-tariksa Nasional. PIT MAPIN XVII, Bandung, 10-12-2008.

Indriatmoko, Haryono. (2010). Teknologi Konservasi Air Tanah Dengan Sumur Resapan. Badan Pengkajian dan Penerapan Teknologi. Jakarta.

Irianto, Gatot. (2006). Pengelolaan Sumber Daya Lahan dan Air Strategi Pendekatan dan Pendayagunaannya. Badan Peneliti-an dan Pengem. Pertanian, Papas Sinar Sinanti, Jakarta.

Maryono, Agus. (2005). Menangani Banjir, Kekeringan dan Lingkungan. Gadjah Mada University Press, Jogjakarta.

Nawawi, Amrayadi. (2004). "Analisis Pemanfaatan Lahan Kota Palembang (Studi Kasus Pemanfaatan Lahan Untuk Peru-mahan di Kota Palembang)." Tesis, Program Studi Ilmu Lingkungan Universitas Indonesia. Jakarta.

Rahim. (2003). Pengendalian Erosi Tanah Dalam Rangka Peles-tarian Lingkungan Hidup. Bumi Aksara. Jakarta.

Rahim dan Halim, P.K.S. (2008). "Panen Hujan Di Lahan Rawa Secara Terpadu." Makalah Seminar Pertemuan Tahunan Il-miah HITI, Palembang 17-18 Desember 2008.

Sibarani dan Bambang, S. (2009). "Penelitian Lubang resapan biopori Untuk Menentukan Laju Resap Air Berdasarkan Va-riasi Umur Dan Jenis Sampah." Skripsi Jurusan Teknik Ling-kungan Fak. Teknik Sipil dan Perencanaan Institut Teknologi Sepuluh Nopember, Surabaya.

Suripin. (2001). Pelestarian Sumber Daya Tanah dan Air. Andi Ofset, Yogyakarta.

United State Environmental Protection Agency. (2009). "Green Roofs for Stormwater Control." (http://www.epa.gov/nrmrl/ pubs/600r09026/600r09026.pdf, diakses 6 September 2010).

Waterfall, P.H. (2007). Rainfall Harvesting For Landscape Use.

John Willey and Sons, New York 